May, Vivian. 2015. Pursuing Intersectionality, Unsettling Dominant Imaginaries. New York: Routledge.

McCall, Leslie. 2005. "The Complexity of Intersectionality." Signs 30 (3): 1771-800.

Nash, Jennifer. 2008. "Rethinking Intersectionality." Feminist Review 89: 1-15.

White, E. Frances. 1990. "Africa on My Mind: Gender, Counter Discourse and AfricanAmerican Nationalism." Journal of Women's History 2 (1): 71-97.

\title{
Reflecting on the Power of hooks
}

doi:10.1017/S1743923X19000667, e22

\section{Shatema Threadcraft \\ Dartmouth College}

I have read and greatly enjoyed bell hooks's classic Feminist Theory: From Margin to Center many times now. I found it browsing the stacks as an undergraduate and returned to it in graduate school. Her statement regarding Betty Friedan so expertly summarized the conflict between black and white feminists, so well captured a conflict whose roots lay in the intersectionality of patriarchal power and its attendant privileges, as well as the failures of recognition those power differences occasioned, that I used part of it as an epigraph in my dissertation and later book, Intimate Justice (Threadcraft 2018). It bears repeating:

[Friedan] did not discuss who would be called in to take care of the children and maintain the home if more women like herself were freed from their house labor and given equal access with white men to the professions. She did not speak of the needs of women without men, without children, without homes ... She did not tell readers whether it was more fulfilling to be a maid, a babysitter, a factory worker, a clerk, or a prostitute than to be a leisure-class housewife. (hooks [1984] 2015, 1-2)

Still as powerful as ever.

It is a pleasure and a privilege to return to the book now, on the occasion of its 35th anniversary. Its insights are as powerful for me now as they were for me at 18. In fact, they are perhaps more powerful for me now, as someone who has taken up hooks's call, who teaches and advances feminist theory.

On this rereading, I was struck by several things. The first is very straightforward: I should teach a class on bell hooks. It is the best and 
most effective way to canonize her. Second, her definition of feminism holds up remarkably well: it is a "struggle to eliminate all forms of oppression" ([1984] 2015, 36). Third, and relatedly, her account of the role that black women, as a collective, must play in producing feminist theory and praxis was diagnostic (she offered examples of what she wanted to see), prefigurative (she did what she told us to do), and prescient (black women did that). Fourth, I am newly inspired by her account of power, a theory of power that she builds from analysis of black women's praxis, to return to the point above, and I want to place her account of power in conversation with agonistic feminism. Finally, I am, however, somewhat skeptical of her claim that Western philosophies of domination are the unitary cause of all the world's violence. That skepticism does not change the fact that this text holds up remarkably well 35 years later. I don't need to say so, but it is indeed a classic.

hooks outlines how feminist movement has proceeded up until the point at which she is writing to motivate her claim that black women must be at the center of producing feminist theory and praxis. The book provides an amazing intersectional analysis of the feminist movement - "Feminist analyses of women's lot tend to focus exclusively on gender and do not provide a solid foundation on which to construct feminist theory" (hooks [1984] 2015, 14) - five years before the article in which Kimberlé Crenshaw coined the term. It then goes on to provide intersectional accounts of feminism, power, and violence. It is a scathing and still accurate critique of unitary analysis of oppression. Bourgeois white women stressed the commonality of women's oppression to build a movement that would address their needs alone - those who critique contemporary carceral feminism as inherently racist would hear this point loud and clear. Because white middle-class feminists had greater access to the tools of mass communication, they were able to represent themselves as women, full stop. These women, hooks says, simply "allowed" black women into "their" movements (11) and encouraged them to share their personal experiences; they set themselves up as white arbiters of the authentic black feminine experience.

The account that hooks gives parallels Frederick Douglass's experience, as abolitionists told him that his job was to provide firsthand accounts of his enslavement, and they would take care of the theory. It is to this, specifically, that hooks is opposed. She says,

Neither the fact that black women have not organized collectively in huge numbers around the issues of feminism (many of us do not know or use 
the term) nor the fact that we have not had access to the machinery of power that would allow us to share our analyses or theories about gender with the American public negates its presence in our lives or places us in a position of dependency in relation to those white and non-white feminists who address a larger audience. ([1984] 2015, 10-11)

She goes on to say,

It is essential for continued feminist struggle that black women recognize the special vantage point our marginality gives us and make use of this perspective to criticize the dominant racist, classist, sexist hegemony as well as to envision and create a counter-hegemony. I am suggesting that we have a central role to play in the making of feminist theory and a contribution to offer that is unique and valuable. The formation of a liberatory feminist theory and praxis is a collective responsibility, one that must be shared. (15)

This statement was at once prescient, as black women would put forward the most influential theory in feminism in the last 30 years, and descriptive, as it was an accurate account of what she herself would go on to do in the book, building from the collective praxis of black women. After this declaration, she provides a definition of (among others) feminism, power, and violence, all of which are worthy of returning to.

Feminism, for hooks, is a struggle to eradicate all oppression from society. Feminism must focus on ending domination. "Therefore," she says, "it is necessarily a struggle to eradicate the ideology of domination that permeates Western culture on various levels, as well as a commitment to reorganizing society so that the self-development of people can take precedence over imperialism, economic expansion, and material desires" ([1984] 2015, 24). Significantly, it is not a struggle for equality with men, nor a struggle to afford greater personal freedom and choice. Her second critique would anticipate critiques of so-called choice feminism. Again, I cannot stress how far ahead of its time this book was.

hooks critiques feminists for being afraid to put forward an affirmative definition of power. Feminists had examples of forms of power that were not domination that emerged out of women of color praxis, but they refused to take them seriously because they were enamored with masculinist definitions of power. The most interesting definition of power that hooks outlines is what she calls "the power of disbelief" ([1984] 2015, 91). She builds on the definition of power advanced by Grace Lee and James Boggs, who say that "No one is talking about real 
power, which involves the reconstruction of the entire society for the benefit of the great majority and for the advancement of humanity" (90). She also builds on a definition advanced by Elizabeth Janeway, from her book Powers of the Weak (1981). hooks says, "One of the most significant forms of power held by the weak is 'the refusal to accept the definition of oneself that is put forward by the powerful"" (90). It is the "ordered use of the power to disbelieve." hooks says,

Women need to know that they can reject the powerful's definition of their reality - that they can do so even if they are poor, exploited, or trapped in oppressive circumstances. They need to know that this exercise of this basic personal power is an act of resistance and strength. Many poor and exploited women, especially non-white women, would have been unable to develop positive self-concepts if they had not exercised their power to reject the powerful's definition of their reality. (90-91)

The problem here is that feminists of the dominant group, those best able to represent their experiences and analysis as all there is, are not looking to groups who have had to create a power resource all their own because of their position in the social structure. hooks believes it is to them we should look. I believe that it is also productive to think about the conception of power hooks wants to advance alongside Arendtian definitions of power as a potential that can exist when people act in concert. This, I think, is what Cathy Cohen would do in "Deviance as Resistance: A New Research Agenda for the Study of Black Politics" (2004), that is, she would theorize about how to make the power to which hooks refers explicitly political. Addressing a similar tendency to ignore marginalized black women among the black elite, Cohen writes,

Despite the feelings of some in Black communities that we have been shamed by the immoral behavior of a small subset of community members, those some would label the underclass, scholars must take up the charge to highlight and detail the agency of those on the outside, those who through their acts of nonconformity choose outsider status, at least temporarily ... These individuals are not fully or completely defining themselves as outsiders nor are they satisfied with their outsider status, but they are also not willing to adapt, or to conform. The cumulative impact of such choices might be the creation of spaces or counter publics, where not only oppositional ideas and discourse happen, but lived opposition, or at least autonomy, is chosen daily. Through the repetition of deviant practices by multiple individuals, new identities, communities, and politics might emerge where seemingly deviant, 
unconnected behavior can be transformed into conscious acts of resistance that serve as the basis for a mobilized politics of deviance. (43)

Finally, I think that it is productive to think about the resonances and challenges that hooks and Cohen together might have for Bonnie Honig's agonistic feminism. All these thinkers give us clues on who we should look to for more and less radical democratic change as well as towards what ends we should direct our agonistic feminism.

In my current work, I am interested in how white power intersects with and, indeed, subjects the black body, male and female, in distinct ways. This power, of course, takes on many forms, but one interesting power formation is the phenomenon of state violence. I have spent much time of late thinking of power from above, of state power, and this time spent with hooks reminded me that the power that concerns me should also be theorized from below.

While I am interested to place her understanding of power in conversation with other feminists, I am less convinced by her unitary account of violence. hooks writes,

While I agree with [Susan] Schechter that male violence against women in the family is an expression of male domination, I believe that violence is inextricably linked to all acts of violence in this society that occur between the powerful and the powerless, the dominant and the dominated. While male supremacy encourages the use of abusive force to maintain male domination of women, it is the Western philosophical notion of hierarchical rule and coercive authority that is the root cause of violence against women, of adult violence against children, of all violence between those who dominate and those who are dominated. It is this belief system that is the foundation on which sexist ideology and other ideologies of group oppression are based; they can be eliminated only when this foundation is eliminated. ([1984] 2015, 118)

I do not believe that violence is a Western phenomenon, though it has been tragically unequally distributed under Western imperialism and its capitalist social relations, so much so that it might appear to have those origins. Nor do I believe that all violence stems from the same source in society. What's more, even if hooks is correct, and all violence stems from the same source, how do we confront the fact that all violence does not concern us equally? That the collective "we" has been more concerned about, and thus devoted more resources to ending, violence against white bodies, violence against male bodies, violence against 
straight bodies. Even if violence stems from a unitary source, it enters a wholly fractured world.

This relatively minor point of disagreement does not change my awe regarding this book. Its theory and analysis remains as powerful as ever, if not more so 35 years later. I am thrilled that it is being given its due in this publication on the occasion of its 35th anniversary, and I hope that generations to come are able to take as much from it as I have.

Shatema Threadcraft is Associate Professor of Government at Dartmouth College: Shatema.Threadcraft@dartmouth.edu

\section{REFERENCES}

Boggs, James, and Grace Lee Boggs. 2008. Revolution and Evolution in the Twentieth Century. New York: Monthly Review Press.

Cohen, Cathy J. 2004. "Deviance as Resistance: A New Research Agenda for the Study of Black Politics.” Du Bois Review: Social Science Research on Race 1 (1): 27-45.

hooks, bell. [1984] 2015. Feminist Theory: From Margin to Center. New York: Routledge. Janeway, Elizabeth. 1981. Powers of the Weak. New York: Morrow Quill Paperbacks.

Threadcraft, Shatema. 2018. Intimate Justice: The Black Female Body and the Body Politic. New York: Oxford University Press. 